\title{
Introducing Rare Books into the Undergraduate Curriculum
}

A Relatively RECENT EXChANGe on the Exlibris listserv inspired me to write this paper. ${ }^{1}$ Julia Walworth, Fellow Librarian at Merton College, University of Oxford, asked about other librarians' experiences in introducing special collections-and rare books in particular - to undergraduate students. ${ }^{2}$ In a nostalgic note, several members of the list responded to Dr. Walworth's inquiry by referring to a course entitled "Fine Arts 5e" that was taught from 1915 through 1932 by George Parker Winship in the Widener Library at Harvard University. ${ }^{3}$ Other responses were more pragmatic in nature, addressing the needs of today's undergraduates. Lori N. Curtis, then Head of Special Collections and Archives at the University of Tulsa, for example, described her outreach efforts in great detail, including an overview of how a class presentation might successfully be used to target some of the themes described in a particular course syllabus. ${ }^{4}$

There were basically two types of responses to Walworth's original query. The first advocated undergraduates learning about the research potential of rare books by

1. I want to thank my colleagues, Phyllis Andrews and Nancy Martin, for their helpful suggestions, as well as Melissa Mead for supplying the digital images. My thanks also go to those Exlibris correspondents who have allowed me to publish their comments. Lastly, I want to express my gratitude to the Bodleian Library, University of Oxford, for granting permission to publish the image of MS Holkham, Misc. 48, p. 27.

2. Julia Walworth, Exlibris, 3/10/04.

3. David Klappholz, Exlibris, 3/10/04; Richard J. Ring, Exlibris, 3/10/04; Adam G. N. Moore, Exlibris, 3/10/04. Asked by William A. Jackson how he selected the students for this course, Winship replied: "Whiskey breath and club pin." The main source of this anecdote seems to be William A. Jackson, himself, as Roger Stoddard recalls in a 1987 paper on the teaching of the history of the books at Harvard. See Roger E. Stoddard, A Library-Keeper's Business (New Castle: Oak Knoll Press, 2002), pp. 15-25; Michael B. Winship, "Fine Arts 5e: the Invention and the Aftermath," in George Parker Winship as Librarian, Typophile and Teacher (Cambridge: Harvard College Library, 1999), pp. 28-40; Thomas R. Adams, "George Parker Winship and Rare Book Collections," The Book Collector, 48 (Spring 1999): 86-100. For a general survey of how liberal arts colleges are introducing special collections to undergraduates, see Susan M. Allen, "Rare Books and the College Library: Current Practices in Marrying Undergraduates to Special Collections," Rare Books \& Manuscripts Librarianship, 13:2 (Spring 1999): 110-19. As regards the role of student bookcollecting contests in undergraduate education, see Donald Farren, "What is Book Collecting? The Case of Student Book-Collecting Contests: their Origins,” RBM, 2:1 (Spring 2001): 48-72.

4. Lori N. Curtis, Exlibris, 3-11-04. 
taking a course on the history of the printed book in the West, which would most likely emphasize socio-economic factors, as described in the now famous 1958 publication, L'Apparition du livre, by Lucien Febvre and Henri-Jean Martin. The second type of response suggested that the rare book librarian work closely with a faculty member to show students how primary source material offers new perspectives that can lead to original research. In taking the second approach, the rare book librarian assumes the challenging and critical roles as both teacher and interpreter of the collection, which may deal with topics beyond his or her area of expertise. Taking on these roles can also be difficult when the special collection librarian has severe time limitations. (I suspect that other rare book librarians also have horror stories to share, such as being asked to present our rich holdings in English Restoration Drama in fifteen minutes or less.)

A class presentation such as that described by Ms. Curtis may provide an exceptional opportunity for undergraduates to learn about the research potential of rare books- "exceptional" because primary sources are often neglected in many undergraduate courses that emphasize the role of literary theory, or "cultural studies." In my own role as Rare Books and Special Collections Curator at the University of Rochester, I have used class presentations both as a way to inspire undergraduates in their research endeavors and as an introduction to some of the methodological premises contained in the discipline of the History of the Book. ${ }^{5}$ I usually work directly with an instructor to arrange these special lectures. In general, professors have enthusiastically embraced the idea that students be exposed to the contents of our collection, and are usually open to the choice of themes I suggest to address, or complement, the content of the course syllabus. In my preliminary conversations,

5. Since the bibliography on this field is already extensive, I will not attempt to be exhaustive but will cite some of the most important studies dealing with the social, intellectual, and economic implications of printing. Indeed, many of these studies also deal with the book in manuscript form. Lucien Febvre and Henri-Jean Martin, L'apparition du livre (Paris: Éditions A. Michel, 1958). Rudolph Hirsch, Printing, Selling and Reading, 1450-1550 (Wiesbaden: Harrassowitz, 1967). Hirsch, The Printed Word: Its Impact and Diffusion (primarily in the 15th-16th centuries) (London: Variorum Reprints, 1978). Elizabeth L. Eisenstein, The Printing Press as an Agent of Change: Communications and Cultural Transformations in Early Modern Europe (Cambridge: Cambridge University Press, 1979). Eisenstein's monograph should be read along with Michael Hunter, "The Impact of Print," The Book Collector 28 (Autumn 1979): 335-52; Paul Needham, "Review of Eisenstein's The Printing Press as an Agent of Change," Fine Print 6, no. 1 (January 1980): 23-25, 32-35; Anthony T. Grafton, "The Importance of Being Printed," Journal of Interdiciplinary History 11:2 (Autumn 1980): 265-86; Peter F. McNally, ed., The Advent of Printing: Historians of Science Respond to Elizabeth Eisenstein's The Printing Press as an Agent of Change (Montreal: Graduate School of Library and Information Studies, McGill University, 1987). For a challenge to one of Eisenstein's main views, that printing established texts more securely than did manuscripts, see Adrian Johns, The Nature of the Book: Print and Knowledge in the Making (Chicago: University of Chicago Press, 1998). For a review of the history of the book in Britain and America, see David McKitterick, "Histories of the Book," The Book Collector 49 (Spring 2000): 9-26. For a bibliographical analysis of the discipline itself, see D. F. McKenzie, "History of the Book," in The Book Encompassed: Studies in Twentieth-Century Bibliography, ed. Peter Davison (New Castle: Oak Knoll Press, 1998), pp. 290-301. For new methodological approaches, see Thomas R. Adams and Nicolas Barker, "A New Model for the Study of the Book," in A Potencie of Life: Books in Society: The Clark Lectures 1986-7, ed. Nicolas Barker (London: British Library, 1993), pp. 5-43. 
I always request that I have an entire class period (either fifty minutes, or one and a quarter hours) in which to work.

I have often delivered a general presentation on the impact of printing in the West, or on the transition from manuscript to print culture, for undergraduate classes such as Europe before 1492 (History), Introduction to Media Studies (English), and Introduction to Art History (Art History). On a long seminar table I will display a selection of medieval manuscripts as well as early-printed books as examples of format, typography, illustration, binding structures, and the making of paper. When working with a large group, the use of digital slides has proven to be essential for emphasizing specific features in a manuscript or printed book: rubrication, ownership inscriptions, scholarly marginalia, marks of censorship, binding structure and decoration, colophons, title pages, watermarks, and the like. Subsequently, these elements are placed in the broader context of the cultural and social transformations taking place in fifteenth-century Europe through questions I pose, such as: What does the working of a printing establishment tell us about society in Early Modern Europe? What can these rare books teach us about reading practices during the Renaissance? Can the layout of early-printed books illustrate the persistence of medieval cultural features? What are the intellectual implications of a fifteenth-century printed edition of 200 copies? The course instructor then provides the crucial link between these questions and particular subjects that are being covered in the syllabus. Students always seem to respond positively to this format of lecture and discussion, particularly as they learn that rare books can play a central role in their subsequent work on research papers. It is important to note that for this type of structure to work, I consider it essential that before giving my class, I discuss with the professor how he or she might use my presentation to discuss some of the broader issues covered in the course content. I have also designed class presentations from a narrower perspective, using our collections to illustrate a specific topic or the work of a particular author. In the next pages, I briefly describe three case studies derived from three different class presentations. As I did in presenting the general lectures mentioned above, I displayed the rare books on a seminar table and again added digital slides in a Power Point format whenever a clearer image was necessary for the discussion. In the final section of this article, I describe a digital project, The Book of the Month Web Page, that was created as a result of my experience teaching undergraduates. Both the design and scope of this digital initiative echo the overall philosophy behind these class presentations.

For a class on Italian Literature, I selected La Comedia di Dante Aligieri con la nova espositione di Alessandro Vellutello (Venice: Francesco Marcolini, 1544). ${ }^{6}$ My presentation dealt with a topic that was not covered in the course syllabus, namely the

6. Ruth Mortimer, Catalogue of Books and Manuscripts: Pt. 2, Italian 16th Century Books (Cambridge: Belknap Press, 1974), pp. 207-11. 
iconography of La Commedia in both manuscript and printed form. Particularly, I explained that in order to understand the rapid canonization of La Commedia, it is crucial to acknowledge the material, artistic, and scholarly efforts involved in the creation of illuminated manuscripts and the first printed editions. Indeed, shortly after Dante completed his poem, manuscript illuminators enthusiastically attempted to render in colorful miniatures the poet's graphic descriptions of the Inferno, Purgatorio, and Paradiso, and more than fifteen commentaries on La Commedia were written in the two centuries following Dante's death. ${ }^{7}$ Following a close examination of a manuscript illumination (see figure 1) along with a sixteenth-century printed edition (see figure 2), I would then raise questions about the transition from a manuscript to a print culture and, more ambitiously, ask whether this material evidence enabled us to recreate, or at least approach, the intellectual experience of readers in the fourteenth and sixteenth centuries. In other words, I wanted to convey the idea that both the iconography and the commentaries are essential elements in the historical experience of reading Dante's poem.

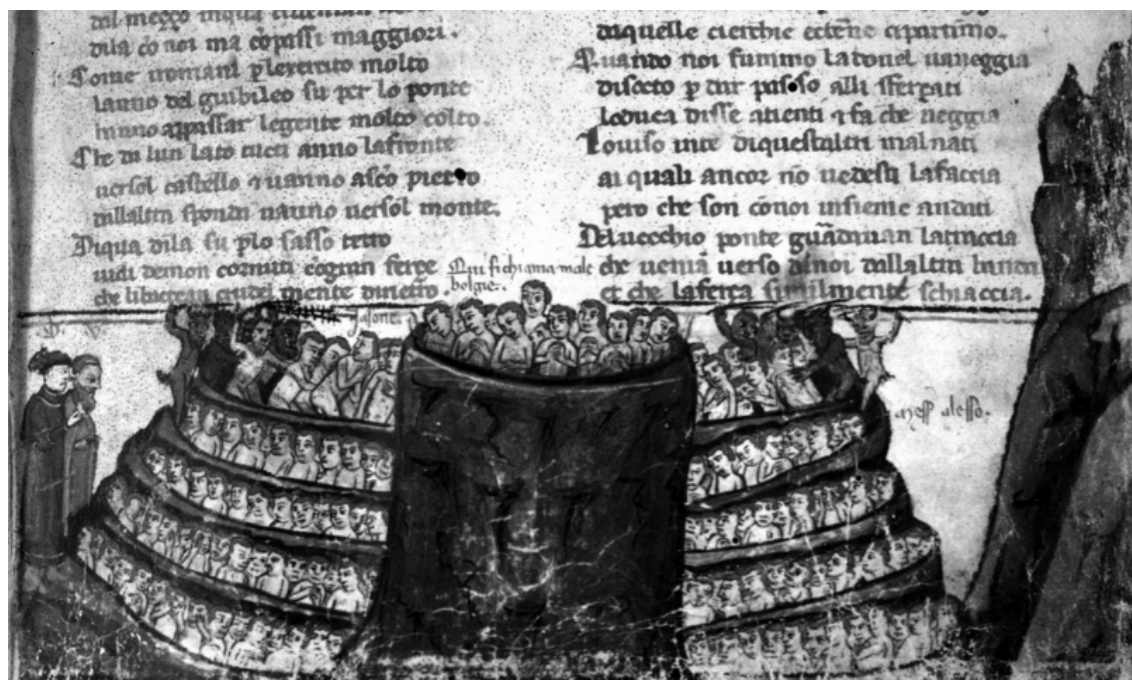

Figure 1. MS Holkham Misc. 48, p. 27. With permission of the Bodleian Library, University of Oxford.

The image illustrated here (figure 1) is from a parchment manuscript of $\mathrm{La} \mathrm{Com}$ media, copied in northern Italy in the third part of the fourteenth century. In Canto XVIII, the monster Geryon set down both Dante and Virgil at the entrance of the eighth circle of hell. ${ }^{8}$ The artist faced the challenge of representing the topogra-

7. For commentaries written in the fourteenth century, see Siro A. Chimenz, "Dante," in Letteratura Italiana (Milano: Carlo Marzorati, 1956), pp. $70 \mathrm{ff}$. See also Aldo Vallone, Storia della critica dantesca dal XIV al XX secolo (Milano: F. Vallardi, 1981), and Deborah Parker, Commentary and Ideology: Dante in the Renaissance (Durham: Duke University Press, 1993).

8. For a detailed description of this particular miniature, including comparisons with other manuscripts that illustrate the same scene, see Peter Brieger, Millard Meiss, and Charles S. Singleton, Illuminated Manuscripts of the Divine Comedy (Princeton: Princeton University Press, 1969), pp. 138-40. 
phy of a subdivision of the eighth circle: the malebolge, which, according to Dante, resembles the ground plan of a castle encircled by moats spanned by bridges. In turn, the malebolge is composed of ten descending concentric circles, in which

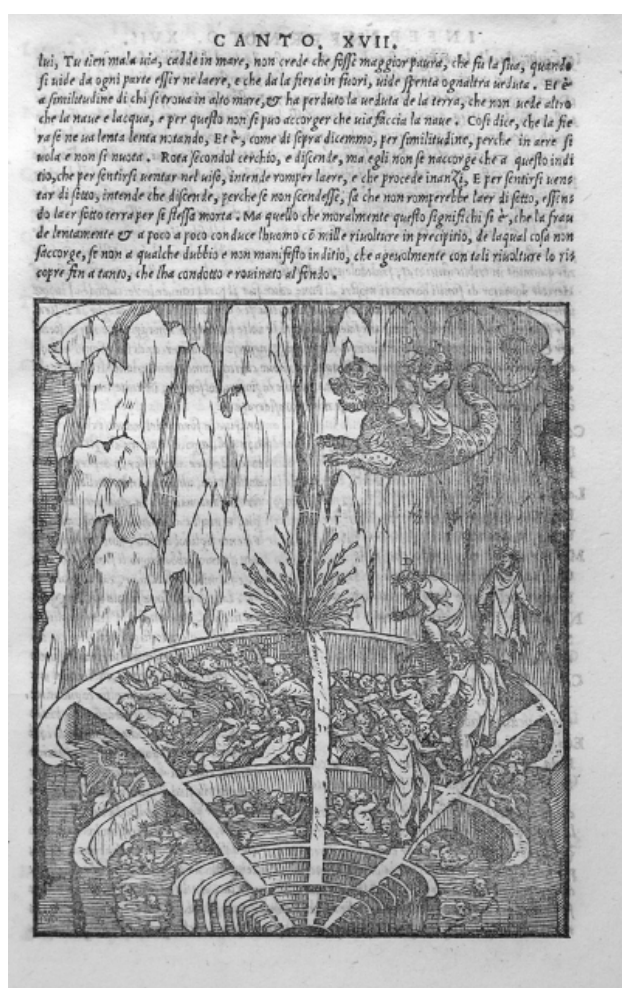

Figure 2. La Comedia di Dante Aligieri con la nova espositione di Alessandro Vellutello. Venice: Francesco Marcolini, 1544. Courtesy of Rush Rhees Library, University of Rochester. panderers, seducers, and flatterers are punished. Horned devils lash the condemned, who run in two circles that move in opposite directions. The artist of this particular manuscript was unable to replicate what Dante described as a bird's-eye view showing a yawning abyss but, instead, designed a round castle keep with five circular moats arranged on terraces.

On the other hand, La Comedia di Dante Aligieri con la nova espositione di Alessandro Vellutello, an edition printed in 1544 by Francesco Marcolini, clearly shows that the woodcut designer was able to overcome the perspective challenges successfully (see figure 2). Vellutello, joining a long tradition of scholarly commentaries on $\mathrm{La}$ Commedia, strongly criticizes previous editors, including Cristoforo Landino and Pietro Bembo. While earlier commentators emphasized the literary aspects of La Commedia, Vellutello considers the poem as an encyclopedic source from which one could draw various ingenious reconstructions, including historical events and the topography of hell. Indeed, the designer of the woodcuts in this particular edition sometimes appears to be following the commentary rather than the main text.

One may argue that topics such as manuscript illumination or Dante scholarship deserve a more comprehensive examination. I would insist, however, that the role of these presentations, as I will show in the next two examples, is to select some examples of how the physicality of the book, manuscript, or printed material can provide the students with new perspectives to explore specific themes of the course. For instance, Dante is often mentioned as an example of both change and continuity, as a paradigm of the transition between the Middle Ages and Renais- 
sance humanism. Similarly, the students can see that the sixteenth-century edition of Vellutello physically mirrors the old scholastic approach of biblical exegesis. The italic type and the overwhelming presence of the commentaries prove that the persistence of manuscript features in printed works is not restricted to fifteenthcentury books.

For a class on the History of Science, I concentrated on the topic of censorship in the first two centuries of printing. First, I broadly referred to the fact that title pages often inform us about the concepts of imprimatur and privilegium, or the right to publish a particular title after approval of the manuscript by the relevant authority. Second, by examining our copy of the second edition of Copernicus' De revolutionibus (see figure 3), ${ }^{9} \mathrm{I}$ had the opportunity to elaborate on the "delicate" ways in which Church censorship could come into play. Following the Council of Trent (1545-1564), the Index librorum prohibitorum included a number of Protestant authors such as Georg Joachin Rheticus, Copernicus' disciple and the author of

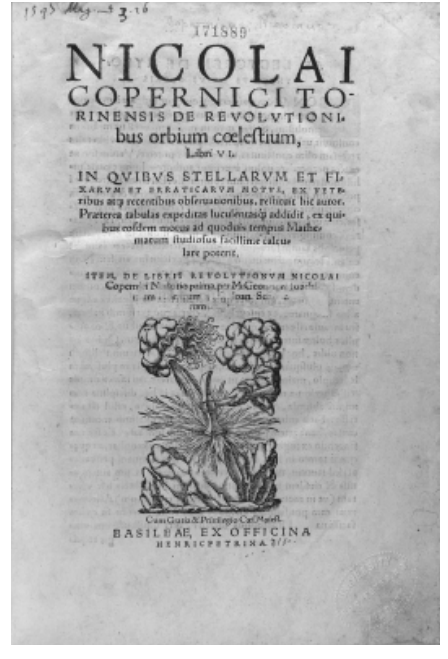

Figure 3. De revolutionibus orbium coelestium. Basel: Heinrich Petri, 1566. Courtesy of Rush Rhees Library, University of Rochester. the Narratio Prima (a summary of Copernicus' treatise), and Johann Schöner, the dedicatee of Rheticus' treatise. Our copy at the University of Rochester has the Narratio prima cut out, and the names of Rheticus and Schöner pasted over.

The first edition of De revolutionibus in 1543 included the famous anonymous foreword, in fact written by Andreas Osiander, a Lutheran clergyman of Nuremberg, which stated: "these hypotheses need not be true nor even probable." ${ }^{10}$ Since the implication was that this treatise should not be read as containing definitive theses, but rather only hypotheses, the Church did not act immediately after its publication. But in 1616 the Inquisition placed De revolutionibus on its Index of Prohibited Books pending such time as specific corrections were made to the text. This was an extraordinary action since for very few books did the Index ever provide details as to the nature of the required corrections. In 1620 , in Decree XXI, the corrections were

9. Owen Gingerich, An Annotated Census of Copernicus' De revolutionibus (Nuremberg 1543 and Basel, 1566) (Leiden: Brill, 2002), p. 341.

10. Owen Gingerich, Eye of Heaven: Ptolemy, Copernicus, Kepler (New York: American Institute of Physics, 1993), pp. 269-85. 


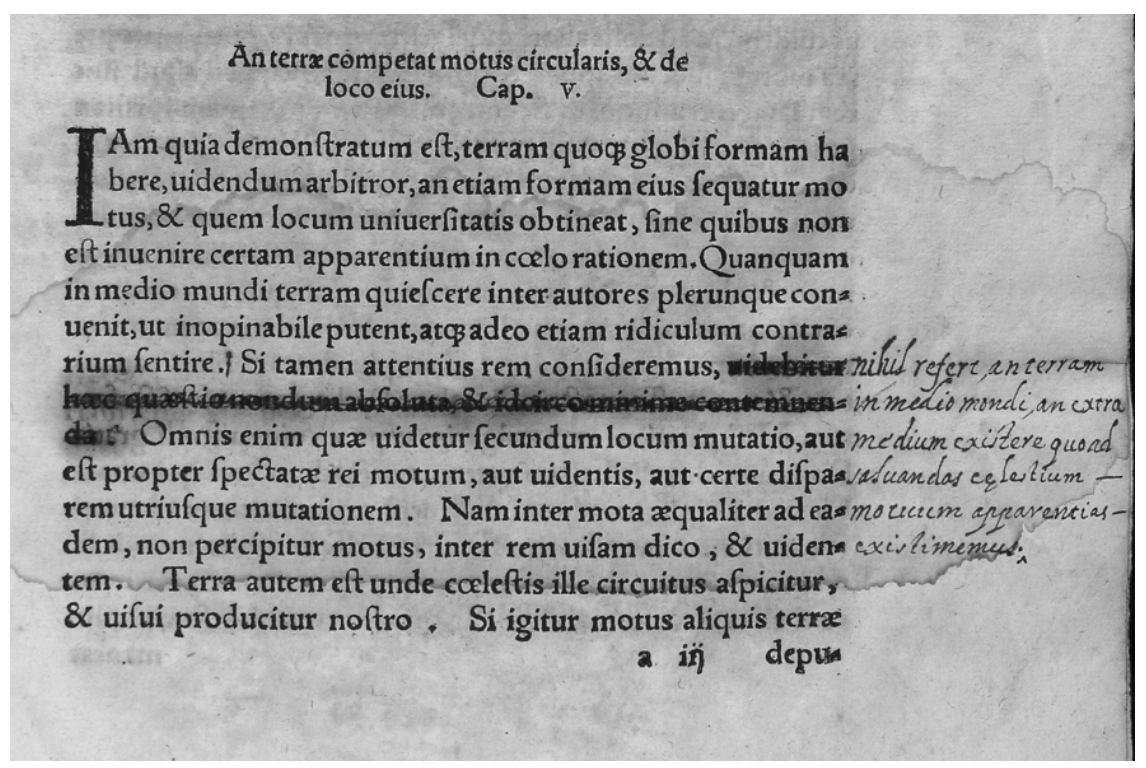

Figure 4. In book 1, chapter 5, a passage has been replaced according to the Index. De revolutionibus orbium coelestium. Basel: Heinrich Petri, 1566. Fol. 3r. Courtesy Rush Rhees Library, University of Rochester.

announced, which included ten emendations designed to make Copernicus' book appear hypothetical and not the description of a real, physical work (see figure 4). Although such corrections were prepared and formally approved in 1620, De revolutionibus remained on the Index until 1835.

For a course on Cervantes' Don Quixote, I chose to illustrate how a particular reading of the novel contributed to its literary canonization. The deluxe 1738 edition I selected, sponsored by Lord Carteret, the second Earl of Granville (1690-1763), is a perfect example of the culmination of this process. ${ }^{11}$ The allegorical frontispiece (see figure 5) can be read as a manual on how to interpret the novel: Cervantes, himself, is described as Hercules Musagetes, avenger of the Muses. Bearing a lyre in one hand, he strides up the path of Mount Parnassus to receive his weapons from a satyr: a club and the mask of Don Quixote. On top of the hill, we can see representations of the grotesque elements of the novel: a giant, a three-headed man, and a multiheaded serpent. As John Oldfield indicated in the "Advertisement Concerning the Prints," the fact that Cervantes, or Hercules, is wearing the mask of Don Quixote announces that the novelist will be using the elements of satire to enlighten the reader, the final objective being to restore the muses to their seats. In other words, Mount Parnassus signifies society conquered by the fantastic monsters of chivalry novels. What the frontispiece echoes is the neoclassical interpretation of the novel:

11. See our Book of the Month Web page for further information on this edition: www.library.rochester.edu $/$ index.cfm?PAGE $=3305$. 
the negative example of Don Alonso Quixano represents the dangers of naïve reading. ${ }^{12}$

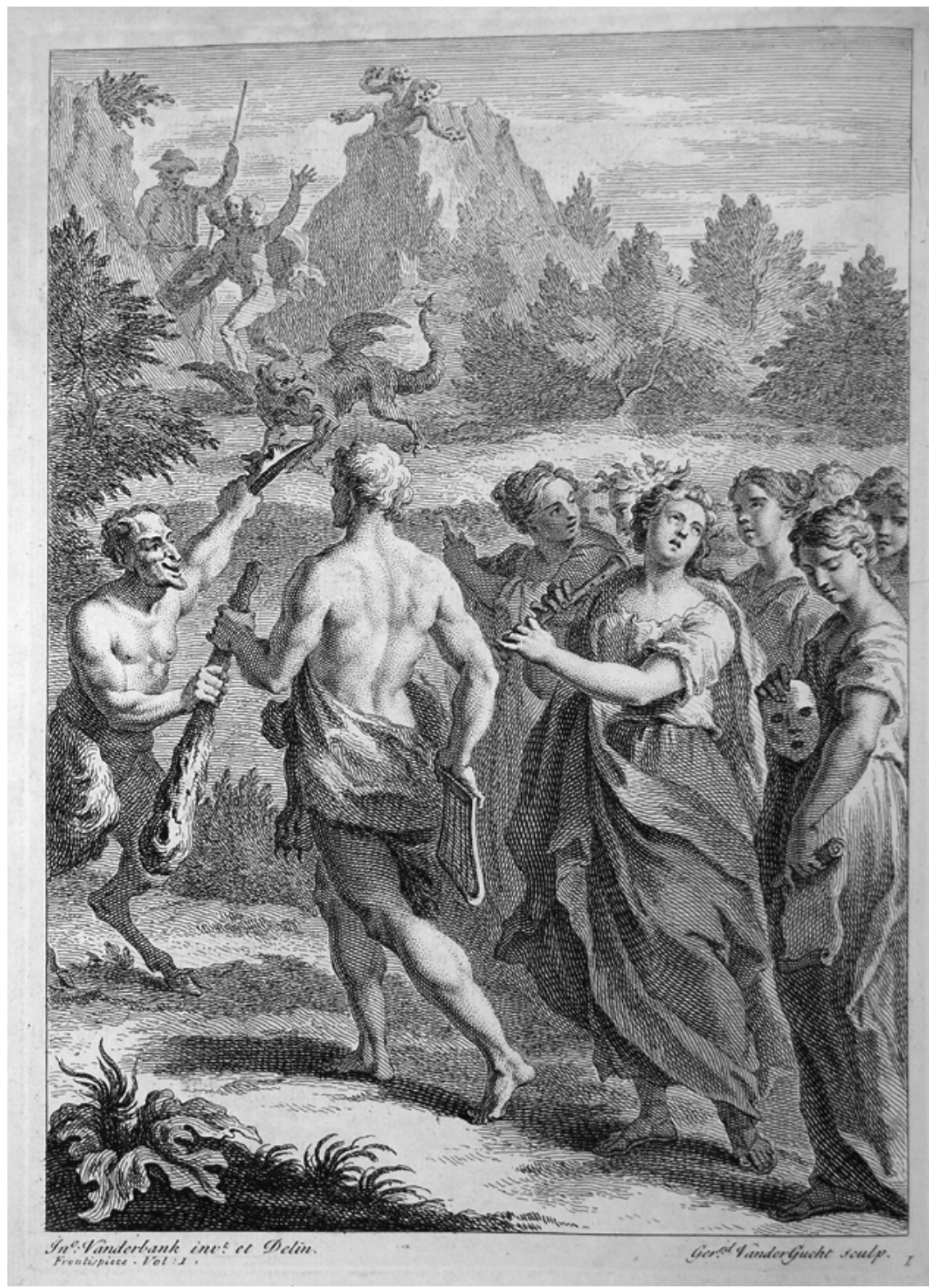

Figure 5. Vida y Hechos del Ingenioso Hidalgo Don Quixote de la Mancha. Compuesta por Miguel de Cervantes Saavedra. En Quatro tomos. London: J. and R. Tonson, 1738. Courtesy Rush Rhees Library, University of Rochester.

12. Rachel Schmidt, Critical Images: The Canonization of Don Quixote through Illustrated Editions of the Eighteenth Century (Montreal: McGill-Queen’s University Press, 1999), 51-55. 
Additionally, something remarkable about our copy is the presence of a modest publisher's binding (unopened in quarter sheep skin over boards), where one would expect to find this profusely illustrated quarto edition bound in calf with gold tooling. ${ }^{13}$ Clearly, this choice of binding enabled the publisher to appeal to a wide range of customers, and in particular the middle class: a new emerging reading public who probably neglected the scholarly advice of Mr. Oldfield and enjoyed the novel as pure entertainment.

The specific elements examined in these three presentations should provide students with a general introduction to some of the principles of the History of the Book. Manuscript illumination, the layout of a commentary apparatus, woodcut illustration, censorship marks, the iconography of the frontispiece, and publisher bindings, are all familiar themes explored by those book historians who, like the authors of L'Apparition du livre, believe that the physicality of the book is vital for the study of the role of the book in society. Inspired by the success of these presentations, as well as their research implications, I recently designed a digital project entitled The Book of the Month. By capturing the somewhat impressionistic flavor of those class presentations, this digital presentation attempts to reflect aspects of the teaching methodology I have employed in the last three years. A thoughtful combination of text and image is designed to create a narrative that not only deals with some unique features of the book under examination, but also helps to address wide-ranging issues about its historical context. ${ }^{14}$

An example can be seen in the feature for the month of November 2005, which was Webber's The Hunter-Naturalist. ${ }^{15}$ The content of this book, which is an interesting combination of outdoor adventure and digressions on natural history, is brought alive in ten plates of chromolithographs. In fact, this is the first time that the process of chromolithography is used in an American book. As stated in the introduction, the author is confident that the technical and economic advantages of chromolithography will be an asset in reaching a wide audience, possibly composed of those readers who enjoyed his previous works on the mythical West. By dealing with the physical aspects of this book, such as the technicalities involved in the process of chromolithography, I am actually echoing the approach used in my class presentations. Indeed, an understanding of the book as an artifact may provide us with crucial information beyond the intellectual content of the work, such as its intended audience and reception.

In conclusion, those bygone days of classes such as those taught by George Parker Winship, where only at certain institutions could an elite group of undergraduate

13. This particular example reinforces Bennett's thesis that British books were often sold in boards and wrappers as well as ready-bound in sheep, calf, and goat. Stuart Bennett, Trade Bookbinding in the British Isles, 1660-1800 (New Castle: Oak Knoll Press; London: British Library, 2004).

14. See, for example, www.library.rochester.edu/index.cfm?PAGE $=170$.

15. Charles Wilkins Webber, The Hunter-Naturalist: Romance of Sporting, or, Wild Scenes and Wild Hunters (Philadelphia: J. W. Bradley, 1851), www.library.rochester.edu/index.cfm?PAGE=3003. 
students and sometimes potential collectors and donors have access to rare book instruction, are largely over. The Exlibris listserv exchange referred to in my opening paragraphs clearly suggests that class presentations for undergraduates have become an ordinary feature in the teaching programs offered by departments of special collections. Furthermore, in partnership with other academic departments such as English, History, and Library \& Information Studies, some departments of special collections are offering courses for credit on the History of the Book. Perhaps the distinguishing feature of my own work that I have highlighted in this article lies in its great emphasis on content and historical context. Admittedly, these presentations are intellectually demanding because they require from the librarian or curator a serious commitment to become reasonably familiar with the specific topics of a given syllabus. Albeit an ambitious approach, it is also true that institutions like the University of Rochester tend to expect their librarians to engage in teaching activities. But the immediate benefits of these presentations fully justify the effort, since undergraduates are provided with a unique opportunity to appreciate the research potential of the rare book collection. Collaborative projects can also help enhance the relationship between departmental faculty and the staff in special collections, opening the doors to other initiatives such as the organization of exhibits, special lectures, and conferences. ${ }^{16}$ Ultimately, the initial burden of preparing these presentations will pay off. A talk on the 1738 London edition of Don Quixote or on the iconography of Dante in the sixteenth century can literally become a work in progress, laying the foundations for more ambitious projects such as The Book of the Month. This, in turn, provides another opportunity to publicize the holdings of the collection. Finally, the interaction with both students and professors can create the necessary learning environment to enable the librarian to develop a credit course on bibliography or on the History of the Book. As a case in point, one of the professors with whom I designed class presentations in 2005 has recently asked me to teach an undergraduate course entitled The History of the Book in the West. Hosted by the Department of History, I began teaching this class in the fall of 2006.

16. For instance, along with the Department of Modern Languages and Cultures, I organized the conference 400 Years of Don Quixote: A Celebration at the University of Rochester (November 2005).

\section{David M. Lesser Fine Antiquarian Books LLC \\ One Bradley Road \#302, Woodbridge, CT 06525 \\ Tel: (203) 389-8111 Fax: (203) 389-9113 \\ Email:dmlesser@lesserbooks.com - Website: http://www.lesserbooks.com}




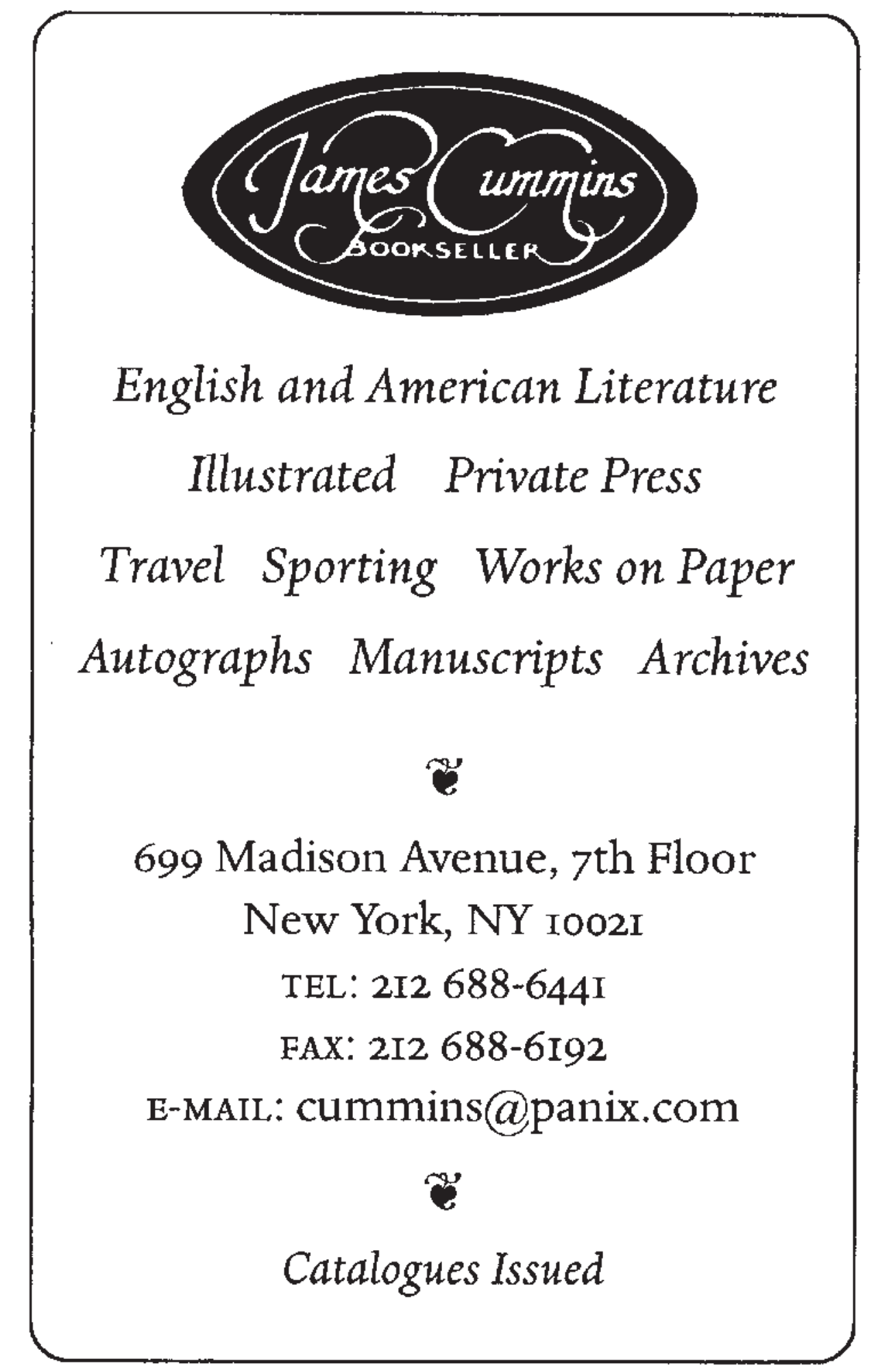

